\title{
Soome- ja venekeelsete õppijate A2- ja B1-taseme keelekasutusmustritest: varieeruvus vs. stereotüüpsus
}

\author{
PILLE ESLON \\ Tallinna Ülikool
}

Ülevaade. Soome ja vene lähtekeelega eesti keele õppijate A2ning B1-taseme tekstide keelekasutusmustrite võrdleva analüüsi tulemused näitavad sihtkeele kasutamisel erinevaid suundumusi. Siinse mõttevahetuse keskmes on leksikaalgrammatilise varieeruvuse ja stereotüüpsuse kujunemine, millel võib olla loogiline seos mõningate keele õppimist mõjutavate asjaoludega (nt õppimise-õpetamise strateegiad, õppematerjalid). Mõtteainet pakub sama sõnaliigijärgnevusega mustrite osakaalu, morfosüntaktilise varieeruvuse ja leksikaalse mitmekesisuse võrdlemine soome ja vene lähtekeelega õppijatel ning emakeelekõnelejatel. Eesmärk on leida eelistused nende mustrite kasutamisel, sõnaliikide kombineerimisel ning sõna- ja vormivalikul. Analüüsi tulemustet nähtub, et soomekeelsete õppijate sõnavara rikastub ja venekeelsetel õppijatel juurduvad leksikaalgrammatilised stereotüübid. Stereotüüpsuse kujunemist põhjustavad a) vähene määrsõnade pagas (soomekeelsetel mitmekesine, venekeelsetel kitsas) ja piiratud arv täistähenduslikke tegusõnu (soomekeelsetel siiski mitmekesisem kui venekeelsetel); b) sõnaliikide ja vormide kombineerimisel toimunud funktsionaalsed nihked emakeelekõneleja keelepruugiga võrreldes (venekeelsed õppijad). Mustri morfosüntaktilise varieeruvuse piire avardab mitmekesise sõnavara kasutamine. 
Märksõnad: keelekasutusmustrid; leksikaalgrammatiline varieeruvus; õppijakeel; eesti keel

\section{Sissejuhatus}

Soome ja vene lähtekeelega ehk soome- ja venekeelsete eesti keele õppijate A2- ja B1-taseme keelekasutusmustrite analüüsiks vajalik allikmaterjal on saadud Eesti vahekeele korpusest (EVKK). Selleks piirati EVKK kasutajaliidese otsinguvõimalusi teksti keeleoskuse taseme (A2 ja B1), autori päritolumaa (Soome ja Eesti) ja emakeelega (soome ja vene). Leitud tekstid jagunesid nelja alamvalimi vahel: kaks neist koosnevad soome lähtekeelega õppijate A2- ja B1-taseme tekstidest, mis kirjutatud Soomes klassiruumi tingimustes; ülejäänud kaks koosnevad vene lähtekeelega õppijate A2- ja B1-taseme tekstidest, mis kirjutatud Eestis keelekeskkonna tingimustes. Soomekeelsete õppijate A2-taseme tekstivalimi maht on 4915 sõnakasutust, venekeelsetel 6601 sõnakasutust. B1-taseme valimid sisaldavad vastavalt 23024 ja 38685 sõnakasutust.

Keelekasutusmustrid on leitud nendest valimitest formaalsete tunnuste alusel EVKK andmekaeve põhimõttel töötava programmiga Klastrileidja. Mustrid eristuvad pikkuse (sõnakasutuste arv) ja struktuuri poolest, millena käsitletakse sõnaliikide regulaarselt korduvat järgnevust morfosüntaktiliselt märgendatud tekstis. Mustrite keeleline varieerumine rajaneb morfo- ja süntaksimärgendite kombineerumisel. Siinne uurimus põhineb kolmest komponendist koosnevatel morfosüntaktilistel mustritel, millest osutusid valituks vaid sama struktuuri ehk sama sõnaliigijärgnevusega mustrid, mis esinesid nii soome- kui ka venekeelsete õppijate keelekasutuses viis ja enam korda. Seejärel võrreldi nende mustrite esinemuse ja keelelise varieeruvuse andmeid soome- ja venekeelsetel õppijatel ning emakeelekõneleja kirjutatud tekstides (andmed saadud artiklist Trainis \& Allkivi 2014: 283-306; Tartu Ülikooli keeleressurssidest on autorid kasutanud allikmaterjalina morfosüntaktiliselt märgendatud korpust, maht ligi 200000 sõnakasutust). 
A2-tasemel on kolmest komponendist koosnevaid mustreid soomekeelsetel õppijatel kokku 3096, venekeelsetel 2865. B1-taseme vastavad andmed on 12035 ja 22201 mustrit. Edasisest analüüsist jäid välja kõik ainukordsed, kaks, kolm ja neli korda esinenud mustrid, sest arvutuste kohaselt ei mõjuta nende esinemus saadud tulemusi. Seega analüüsiti A2-taseme tekstide keelekasutust soomekeelsetel õppijatel tegelikult 227 mustri (7,3\% kõikidest mustritest) ning venekeelsetel õppijatel 203 mustri põhjal (7,1\% kõikidest mustritest). B1-taseme keelekasutust analüüsiti vastavalt 1132 (9,4\% kõikidest mustritest) ja 4363 (19,7\% kõikidest mustritest) mustri alusel. Samalaadse sõnaliikide järgnevusega struktuuride põhjal jagunevad A2-taseme soomekeelsete õppijate mustrid 19 ja venekeelsetel 18 suurema rühma vahel, B2-tasemel vastavalt 18 ja 20 rühma vahel.

Arvandmetest nähtub, et A2-tasemel on viis ja rohkem korda kasutatud mustrite osakaal soome- ja venekeelsetel õppijatel enam-vähem samas suurusjärgus (vastavalt 7,3\% ja 7,1\%). B1-tasemel nende osakaal kasvab: venekeelsetel õppijatel hüppeliselt $(19,7 \%)$ ja soomekeelsetel sujuvalt $(9,4 \%)$. Võrreldes A2-tasemega on venekeelsete õppijate keelekasutusse lisandunud kaks uut mustrirühma (4363 mustrit jagunevad 20 rühma vahel), ent võrreldes A2-taseme 18 mustrirühmaga suureneb nende osakaal ligi kolm korda (18 rühma hõlmavad 7,1\% ja 20 rühma $19,7 \%$ valimist). Seevastu soomekeelsetel õppijatel pole B1-tasemel uusi mustrirühmi lisandunud, võrreldes A2-tasemega on nende arv ühe võrra väiksem (1132 mustrit jagunevad 18 rühma vahel, samas suureneb nende 18 rühma osakaal A2-tasemega võrreldes 7,3\%-lt 9,4\%-ni, st 2,1\% võrra). Eespool kirjeldatud statistilised erinevused tekitavad küsimusi. (Vt ka Eslon jt 2021: 115-204; samuti Eslon \& Kaivapalu 2020)

1. Kui suur hulk viis ja enam korda kasutatud mustritest jaguneb suhteliselt väikese arvu mustrirühmade vahel, mis katavad suurema osa valimist, siis on loogiline järeldada, et keelekasutust ilmestavad kindlat liiki leksikaalgrammatilised stereotüübid, mida tekstis sageli korratakse. Stereotüüpsed sõna- ja vormikooslused on ühtmoodi omased nii õppijakeelele (nt leksikaalgrammatilise kivinemise ilmingud) kui ka 
emakeelekõneleja loomulikule keelekasutusele, nt fraseoloogilised üksused, nende leksikaalgrammatilise varieeruvuse piirid, samuti statistiliselt eristuvad samalaadse vormistusega ütlused nagu on alles perekond (naine, elu, algus, inimesed, suveteed); on alles ees; on alles moodustumas (kogumas hoogu) jmt. Ehkki nimetatud juhtumitel ei saa stereotüüpide tekkepõhjusi ja olemust seletada samade asjaoludega, peaks mustri morfosüntaktilise struktuuri põhjal olema selgelt näha, kuidas kujuneb eesti õppijakeeles stereotüüpsus võrreldes nende keeleomaste piirangutega, mis esinevad emakeelekõnelejal sama struktuuriga mustri morfosüntaktilises ja leksikaalses varieeruvuses. Siit esimene küsimus: millisel määral on A2- ja B1-taseme venekeelsed õppijad eelistanud stereotüüpseid sõnastusi, millest see võiks olla tingitud ning milles täpsemalt väljendub?

2. Kui viis ja enam korda kasutatud mustrite osakaal on B1-tasemele jõudes tõusnud sujuvalt nagu soomekeelsetel õppijatel (osakaal A2-tasemel 7,3\% ja B1-tasemel 9,4\%), ent morfosüntaktiliste struktuuride arv on samas väiksem kui A2-tasemel ning stereotüüpseid sõna- ja vormikooslusi ei esine, siis on loogiline järeldada, et õppijate keelekasutust ilmestab pigem leksikaalne kui grammatiline mitmekesisus. Emakeelekõneleja mustrite hulga ja suhtluseesmärkide järgi valitud morfosüntaktiliste struktuuride vahel valitseb suhteline tasakaal. Üldjuhul ilmestavad mustrite kasutamist mitmekesine sõnavara ning piirangud struktuuride morfosüntaktilises varieeruvuses. Sama suundumus paistab olevat ka soomekeelsete õppijate keelekasutuses. Võrreldes A2-tasemega on neil B1-tasemel morfosüntaktiliste struktuuride arv ühe võrra vähenenud, kuid tekstidest leitud keelenäidete arv seevastu tunduvalt suurenenud. Niisiis on soomekeelsed óppijad olemasolevate mustrite põhjal rikastanud ühelt poolt oma sõnavara ning teisalt laiendanud või hoopiski kitsendanud mustri komponentide grammatilisi funktsioone, ent kokkuvõttes liikunud siiski mitmekesisema lausestuse poole. Kõik see viitab keeleoskuse intensiivsemale arengule, millega kaasneb morfosüntaktiliste struktuuride ratsionaalsem kasutamine. Teisalt ei ole välistatud, et sageli kasutatud morfosüntaktiliste struktuuride vähenemine ja nende alusel moodustatud keelenäidete arvu suurenemine 
võib viidata ka vähesele loomingulisusele. Siit järgmine küsimus: millistele keele õppimise, omandamise ja õpetamisega seotud asjaoludele võiksid viidata õpingute algetapil keelekasutuse stereotüüpsus (venekeelsed õppijad) ja millele sõnavara intensiivne laienemine (soomekeelsed õppijad)?

Selleks, et leida vastuseid esitatud küsimustele, on viis ja rohkem korda kasutatud mustrite seast valitud just need ühesuguse morfosüntaktilise struktuuriga mustrid, mida kasutavad mõlema rühma õppijad. Võrreldakse nende osakaalu ja leksikaalgrammatilist varieerumist A2- ja B1-taseme valimites ning emakeelekõneleja tekstides. Emakeelekõneleja loomulikus keelekasutuses iseloomustab näiteks mustri nimisõna-sidesõna-nimisõna kasutamist rinnastav seos kahe leksikaalselt, grammatiliselt ja funktsionaalselt varieeruva nimisõna vahel ( uksed ja aknad; ukse ja akna; ust ja akent; ukse ja aknaga jne), samas kui soome- ja venekeelsetel õppijatel esineb nimisõna selles mustris alati nimetavas käändes kas aluse või öeldistäite funktsioonis. Mustris tegusõna-asesõna-määrsõna (kuulab teda tähelepanelikult; mängib seda ka jne) kasutab emakeelekõneleja reeglina sihilist tegusõna, millele järgnevad täis- või osasihitis ja erinevat liiki määrused, kuid õppijatel ei kuulu see muster ka B1-tasemel viis ning enam korda esinenud mustrite hulka. Niisiis saab ühesuguse morfosüntaktilise struktuuriga mustrite alusel võrrelda, kuidas sama mustrit eelistab kasutada emakeelekõneleja, kuidas erikeelsed óppijad ning milline on nende mustrite areng A2-tasemelt B1-tasemele liikudes.

\section{Keelekasutusmustrite stereotüüpsus ja nihked võrreldes sihtkeelega}

ÕS 2018 määratleb nimisõna stereotüüp tähendust 'spets kõrgtrükivormi koopia; ülek kinnisarusaam, kivinenud hoiak, käsitus vm' Omadussõnaga stereotüüpne tähistatakse midagi muutumatult järeletehtut; korduvat, šabloonset (nt stereotüüpsed arvamused). Asta Õimu sünonüümisõnastikus on esindatud tähenduselt lähedased sõnad: 
harjumuslik: rutiinne; sissejuurdunud; pindunud (pindunud harjumus); stereotü̈̈p(ili)ne, kivinenult harjumuslik; harjumuspärane; habituaalne; tavakohane; tavapärane; harilik; kindlaks kujunenud; harjunud (harjunud kombe järgi); traditsiooniline; konventsionaalne. Eesti keele tesaurus ei kajasta omadussõna stereotüüpne, vaid stereotüüpiline, mis kuulub samasse semantilisse pessa koos sõnadega harjumuslik, harjumuspärane, habituaalne, tavakohane, tavapärane, harilik, harjunud, traditsiooniline, konventsionaalne, rutiinne, sissejuurdunud. Niisiis tähistatakse sõnadega stereotü̈̈p, stereotüüpne ja stereotüüpiline midagi, mis on tavapärane, rutiinne, juurdunud, kivinenud.

Eespool mainitud neli sõna - tavapärane, rutiinne, juurdunud, kivinenud - iseloomustavad ka keelekasutusmustreid, mida ei rühmitata semantiliste ega grammatiliste tunnuste alusel, vaid leitakse morfosüntaktiliselt märgendatud tekstidest morfoloogiliste ja süntaktiliste märgendite samalaadse regulaarse koosesinemise põhjal automaatselt. Märgendite formaalkeel võimaldab andmekaeve meetodil statistiliselt esile tuua ja klassifitseerida erineva pikkusega mustreid, mis ei lange kokku konstruktsioonide, seotud sõnaühendite, idioomide, väljendite ega muud liiki fraseoloogiliste üksustega, kuid võivad neid (osaliselt) sisaldada. Üksus tervikuna hargneb lahti kas mustri parem- või vasakkontekstis. Emakeelekõnelejal tekitavad niisugused mustrid automaatselt assotsiatiivseid seoseid eelneva/järgneva konteksti sõnastusvariantidega, nt kolmest määrsõnast koosneva mustri kasutamisel: minge otse edasi umbes 100 meetrit ja; ka ikka tuubil täis; Veel edasi vasakule umbes kaks kilomeetrit ja oletegi kohal; saame kokku ka täna kell kuus. Samalaadi seoseid tekitavad mustrid, mille morfosüntaktilise struktuuri alusel saab moodustada ja kasutada analüütilisi liittegusõnu, nt tegusõna + määrsõna + tegusõna (püüdis ära tunda - ühendtegusõna); tegusõna + nimisõna + nimisõna (andis jalgadele valu - väljendtegusõna) jne.

Niisiis on keelekasutusmuster juba oma olemuselt tüüpilise vormija sõnakasutusega tekstiüksus, mille komponentide leksikaalgrammatilise varieeruvuse võimalused on talletatud keelemeeles. Selliste 
tekstiüksuste alusel tulevad ilmsiks ka autorikeele isikupärased jooned, stiili- ja žanrierisust märkivad tüüpilised sõnastused, mis kinnistunud kindlate suhtlusvajadustega ning mis keelekogukond omaks võtnud. Keelekasutusmustrid väljendavad samaaegselt nii individuaalselt variatiivset kui ka ühiskondlikult aktsepteeritud sõnastamise viisi, mis on juurdunud emakeelekõneleja keelepruugis.

Sihtkeele omandamine eeldab, et õppijal areneb järk-järgult välja oskus kasutada sihtkeele vahendeid analoogselt emakeelekõnelejaga. On selge, et A2- ja B1-tasemel ei ole õppijad veel sedavõrd vilunud. Esiteks on nende tekstides asendunud loomulik keeleline varieeruvus osaliselt stereotüüpsete sõnastustega. Teiseks tuleb samade mustrite puhul võrreldes emakeelekõneleja keelekasutusega esile mitmesuguseid nihkeid ehk osalisi muudatusi, mis on seotud õppija tehtud valikutega ning mille tulemusel a) emakeelekõneleja tekstides sageli esinevatele mustritele eelistatakse harva kasutatavat; b) emakeelekõneleja tekstides levinud mustrile eelistatakse selle harva esinevat leksikaalgrammatilist varianti; c) nihked loomuliku keelekasutuse suhtes puudutavad ka mustri komponentide järjestust (sõnajärg), sõna(vormi)de kombineerimise viisi, mustri komponentide süntaktilisi funktsioone.

\subsection{Stereotüüpne vs. varieeruv}

Stereotüüpsuse ilmnemine venekeelsete õppijate A2- ja B1-taseme tekstides on ühelt poolt seotud asesõna, määrsõna ja sidesõna kasutamisega ning teisalt tegusõnade vähese leksikaalse varieerumise ja abitegusõna olema kinnistumisega kindla kõneviisi olevikus, harvem lihtminevikus. Järgnevalt näiteid selle tõenduseks.

Muster asesõna-tegusõna-määrsõna on venekeelsetel õppijatel kinnistunud A2-tasemel leksikaalgrammatilises variandis see on väga. B1-tasemel suureneb mustri osakaal õppijate tekstides lausa hüppeliselt (vt joonis 1), rööpselt laieneb ka mustri komponentide leksikaalne ja morfosüntaktiline varieerumine, kuid sellele vaatamata eelistavad venekeelsed õppijad endiselt rõhusõna väga, näitavat asesõna see 
ja abitegusõna olema kindla kõneviisi olevikus. Niisiis pole mustri stereotüüpne kasutus see on väga (harvem see on kõige) asendunud leksikaalselt varieeruvaga. Samas eelistavad soomekeelsed õppijad isikulist asesõna kasutada koos erinevate täistähenduslike tegusõnadega, abitegusõnaga olema esineb harvem (nt ma ópin kiiresti; me jalutasime kaua; mul on vaja), näitavat asesõna kasutatakse vaid üksikjuhtudel (nt see oli natuke; see on nii). Niisiis toob muster asesõna-tegusõna-määrsõna esile kaks vastandust: isikulised asesõnad ma-me soomekeelsetel õppijatel $v s$. näitav asesõna see venekeelsetel ning täistähenduslikud tegusõnad soomekeelsetel õppijatel $v s$. abitegusõna olema venekeelsetel. Erinev on ka määrsõna leksikaalne varieeruvus.

Näitava asesõna stereotüüpi et (sest) see on eelistavad venekeelsed õppijad muuhulgas ka leksikaalgrammatiliselt varieeruvas mustris sidesõna-asesõna-tegusõna, nt et nad on; et ma óppisin; et mul ei ole; siis sul/ tal on; aga ma arvan jne. Näitava asesõnaga mustri stereotüüpsust rõhutavad alistav sidesõna et mustri alguses ning mustri lõpus abitegusõna olema kindla kõneviisi olevikus. Soomekeelsetel õppijatel asesõnalist stereotüüpi ei teki, sest a) mustrit sidesõna-asesõna-tegusõna kasutatakse kitsamal suhtluseesmärgil mina-keskses kirjelduses, mistõttu on ka muster mofosüntaktiliselt vähem varieeruv; b) seosed mustrist vasakule hargneva kontekstiga on semantiliselt mitmekesised, mida näitab erinevat liiki sidesõnade kasutamine; c) muster tervikuna on leksikaalselt rikkalikum kui venekeelsetel õppijatel, nt et ma ei; aga ma ei saa; kui mul on; siis ma jooksin; siis me jalutasime; et ma võiksin.

Mustris tegusõna-määrsõna-omadussõna kasutavad venekeelsed õppijad A2-tasemel stereotüüpselt rõhumäärsõna väga koos abitegusõnaga olema kindla kõneviisi oleviku vormis (on väga sõbralik). Leksikaalselt varieerub vaid omadussõna. B1-tasemel on määrsõnu küll juurde tulnud, kuid valdab siiski stereotüüp on väga + omadussõna, harvem ülivõrre (nt on kõige suurem). Mustri osakaal emakeelekõneleja tekstides on seevastu väheoluline.

Määrsõnadega on venekeelsetel õppijatel kujunenud ka teistlaadi stereotüüpe. Näiteks B1-taseme tekstides kombineeritakse omavahel 
kolme määrsõna väga, palju ja vaja, sh mustris tegusõna-määrsõnamäärsõna (on vaja palju; on palju vaja; on vaja väga; on väga vaja; on/ oli väga palju). Niisuguseid määrsõnakooslusi ei esine soomekeelsetel õppijatel (nt on nii palju; on ka väga), kes sarnaselt sihtkeelega kasutavad koos erinevaid määrsõnu nagu oli küll lähedal; on ikkagi üleliia.

Mustris tegusõna-määrsõna-omadussõna esineb soomekeelsetel õppijatel juba A2-tasemel neljast sõnast koosnev määraskaala (mõnevõrra $>$ üsna $>$ eriti $>$ väga), mis B1-tasemel täieneb (mõnevõrra > natuke $>$ üsna $>$ päris > eriti > väga), samas kui venekeelsed õppijad kasutavad stereotüüpselt rõhusõna väga (on väga ilus). Mustris tegusõna-tegusõnamäärsõna kasutavad soomekeelsed õppijad seitsmest sõnast koosnevat määraskaalat (üldsegi/sugugi $>$ eriti $>$ natuke $>$ rohkem $>$ päris $>$ küllalt $>$ piisavalt > palju), ent venekeelsed õppijad kordavad tüüpiliselt nelja sõna (väga, nii, palju ja kõige). Olgugi et B1-tasemel täieneb mõlema rühma õppijate määrsõnade pagas, on venekeelsetel see endiselt kasin ning endiselt eelistatakse rõhusõna väga (nt on väga vana; oli väga huvitav) ja ülivõrde vormi (nt on kõige parem).

Niisiis rajanevad asesõnalised ja määrsõnalised stereotüübid venekeelsete õppijate A2- ja B1-taseme tekstides kesisel sõnavaral, k.a piiratud arv tegusõnu ja sidesõnu. Mustrites tuleb esile konkreetne teemakeskne sõnavara, abstraktseid mõisteid peaaegu ei kasutata. Näiteks tutvustatakse iseennast ja oma peret või lähikonda (muster asesõna-nimisõnategusõna - minu nimi on; minu isa on), kirjeldatakse oma korterit, maja, asukohta, õpinguid (muster nimisõna-tegusõna-nimisõna - ${ }^{\star} k$ öögikapil on kiirkeetja <kiirkeetja on köögikapi peal>) jne. Samas kasutab emakeelekõneleja mustreid, milles eelistab abitegusõnale olema a) täistähenduslikke sihilisi tegusõnu koos järgneva täis- või osasihitisega, nt muster nimisõna-tegusõna-nimisõna - Jumal lõi maailma; tüdruk surus nina aknaklaasi vastu; b) täistähenduslikke tegusõnu koos eelneva asesõna või nimisõnaga aluse funktsioonis, nt asesõna-nimisõna-tegusõna (see töö edenes; mu grimassid vaheldusid; ta prillid läigatavad) või nimisõnategusõna-määrsõna (helk kumas otsekui; töö edenes vaevaliselt; meel oli väga). 
Analoogne suundumus tuleb esile ka uutes, alles B1-tasemel lisandunud sama morfosüntaktilise struktuuriga mustrites:

1) mustris omadussõna-nimisõna-tegusõna eelistab emakeelekõneleja erinevaid täistähenduslikke tegusõnu (noored naised meeldivad; paha lugu juhtus; vintske vanamees suri; täielik hullumeelsus oli) ja venekeelsed õppijad abitegusõna olema (suur isu on; peamised töökohustused on; uus välisminister on; järgmine suvi on; Keskmine pension on; Toimiv koostöö on);

2) mustris sidesõna-omadussõna-nimisõna varieerib emakeelekõneleja rinnastavaid sidesõnu (ja valge karikakar; aga tüütu karvanäss; ning vana karvamüts), kuid venekeelsed õppijad eelistavad alistavat sidesõna et (et positiivne ellusuhtumine; et järgmine suvi; et eestikeelne versioon; et noor poiss; sest ${ }^{*}$ väike $<$ vähene> praktika);

3) mustris määrsõna-määrsõna-omadussõna kasutab emakeelekõneleja rikkalikult mitut liiki määrsõnu, sama tuleb esile ka soomekeelsete õppijate tekstides (üldsegi mitte uje; rahvast $\underline{i k k a}$ tuubil täis), kuid venekeelsed õppijad eelistavad endiselt ühte määrsõna, antud juhul rõhusõna nii (praegu nii hull; mitte nii oluline; küll nii tugev).

Nagu eespool väidetud, on sõnavara laiendamisel mõttekas aluseks võtta tegusõna, sest selle eri tähendused seostuvad erinevate rektsioonimallide ja öeldise liikidega, st lause tuuma erinevate süntaktiliste struktuuridega, millest omakorda sõltub lause moodustajate vajalikkus, võimalikud valikud ja tegusõna-nimisõna sisaldavate idiomaatiliste üksuste kasutamine. Samas on B1-tasemel struktuurilt lihtsa mustri nimisõna-tegusõna-nimisõna kasutamisel sihilised tegusõnad kõrvale jäänud, kuid emakeelekõneleja eelistab just neid (nt Jumal lõi maailma). Õppija tegusõnade pagasi laiendamisel täistähenduslike sihiliste tegusõnadega tuleb arvesse võtta mitte ainult täis- ja osasihitise valikut ning omastava-osastava käände moodustamist, vaid ka seda, et mustri nimisõna-tegusõna-nimisõna struktuuri alusel kasutatakse idiomaatilisi väljendtegusõnu, mis sisaldavad sihitisekäändelist komponenti (nt poiss 
murrab pead; varas lasi jalga; isa tegi nalja). Samas pole õppijad mustrit nimisõna-tegusõna-nimisõna neil eesmärkidel kasutanud, puudub vajalik tegusõnade pagas.

Ka muster asesõna-tegusõna-määrsõna eeldab erinevate täistähenduslike tegusõnade, sh liittegusõnade kasutamist (nt ühendtegusõnad: ma tulin ära; nad jooksevad alla lähemalt vaatama; ta laskis maha marutaudis koera). Koos uute tegusõnadega tulevad kaasa erinevad süntaktilised struktuurid, mitmekesistub määrsõnade valik, nt ma kavatsen ka mida teha, ma pean tihti mida tegema, me jalutasime kaua kus, mul on vaja mida-keda, mida teha. Kui aga venekeelsed õppijad kasutavad mustris asesõna-tegusõna-määrsõna jätkuvalt näitavat asesõna see, abitegusõna olema ja rõhusõna väga ning täistähenduslikke tegusõnu tuleb üldse harva ette, siis ei tekigi tegusõnaga seotud leksikaalse ja morfosüntaktilise varieeruvuse võimalust ning liitsete tegusõna-määrsõna koosluste kasutamist. Selle asemel vahelduvad tavaliselt isikulised asesõnad subjekti (harva omaja) funktsioonis, nt Mina olen väga (juba); ta on väga (veel, juba, ka, suhteliselt); nad on väga (veel, just, tõesti); Mul on väga, mul on palju, mul on vaja; Mul oli väga, mul oli kõige. Tulemus: laieneb mustri asesõna-tegusõna-määrsõna morfosüntaktiline, mitte leksikaalne varieeruvus. Võrdluseks: emakeelekõneleja loomulikust keelekasutusest leitud näidetes sisaldub rikkalik valik tegusõnu ja määrsõnu, mustri morfosüntaktiline varieeruvus on seotud ennekõike tegusõna ajavormidega, muster avab eesti keele määrsõnade funktsionaalse võimekuse. Selles suunas kulgeb sihtkeele omandamine soomekeelsetel óppijatel klassiruumi tingimustes, kuid venekeelsed õppijad vahetus keelekeskkonnas eelistavad mustrit asesõna-tegusõna-määrsõna kasutada variandis, mida emakeelekõnelejad aktiivselt ei rakenda. Määrsõnade vähene leksikaalne varieeruvus, nende stereotüüpne kasutamine, samuti täistähenduslike tegusõnade vältimine on põhjused, miks tegemist on sihtkeele suhtes nihkes keelekasutusega. See võib mh mõjutada ka eesti keelekeskkonnas suhtlevate inimeste loomulikku keelepruuki. Analoogseid juhtumeid leidub teisigi: muutused sõnajärjes (k.a käändelised määrused), rööpsete rektsioonimallide kujunemine, lihtmineviku 
eelistamine täisminevikule, arengud sihitise käände valikul jm. Neid juhtumeid on analüüsitud ja analüüsitakse ka edaspidi, kuid seoses grammatiliste käänete kasutamisel ilmnenud muutustega on Mati Hint (2017: 175) tabavalt märkinud, et „tähelepanu juhtimine sellistele muutustele on raske, sest $\mathrm{n}$-ö tavaline keeleavalikkus märkab keelemuutusi laensõnade tasandil ning üksikute morfoloogiliste vormide normimuutusi, mitte muutusi konstruktsioonides, mis on keele grammatika tõeline identiteet“. Analoogselt saab mõtestada ka varieeruvuse ja stereotüüpsuse suhestust keelekasutusmustrites. Allpool mõningaid näiteid õppijate nihkes keelekasutusest, mis aja jooksul võivad hakata sihtkeelt ühel või teisel viisil mõjutama.

\subsection{Loomulik vs. nihkes}

Võimalikud nihked sama struktuuriga mustri kasutamisel tulevad ilmsiks võrdluses: a) mustri osakaal erikeelsete õppijate A2- ja B1-taseme tekstides ning emakeelekõneleja kirjutistes; b) mustri leksikaalse ja morfosüntaktilise varieeruvuse piirid emakeelekõnelejal ning erikeelsetel õppijatel A2- ja B1-tasemel; c) emakeelekõneleja loomuliku keelekasutuse eelistused vs. erikeelsete õppijate keelekasutuse eelistused A2- ja B1-tasemel.

Kümne sama struktuuriga mustri osakaalu võrdlusandmed (soomeja venekeelsete õppijate A2- ning B1-taseme tekstid) näitavad, et osa A2-taseme struktuuridest on B1-tasemel kasutusel tunduvalt laiemalt (vt joonis 1), kuid mustrite keeleanalüüsi tulemustest selgub, et just venekeelsetel õppijatel ei kaasne sellega olulisi kvalitatiivseid nihkeid morfosüntaktilises keerukuses, nt sidesõna-asesõna-tegusõna (et ma pean; Siis ma tahtsin); asesõna-tegusõna-määrsõna (Ma tahan ka; see on nii); tegusõna-määrsõna-omadussõna (on väga ilus; on üsna väike). Endiselt on tegusõna kindla kõneviisi olevikus, harvem lihtminevikus; nimisõnad nimetavas käändes aluse või öeldistäite funktsioonis, harva käändelise koha- ja ajamäärusena alalütleva ja seesütleva käände vormis; isikulised asesõnad subjekti (harvem omaja) funktsioonis jne. 


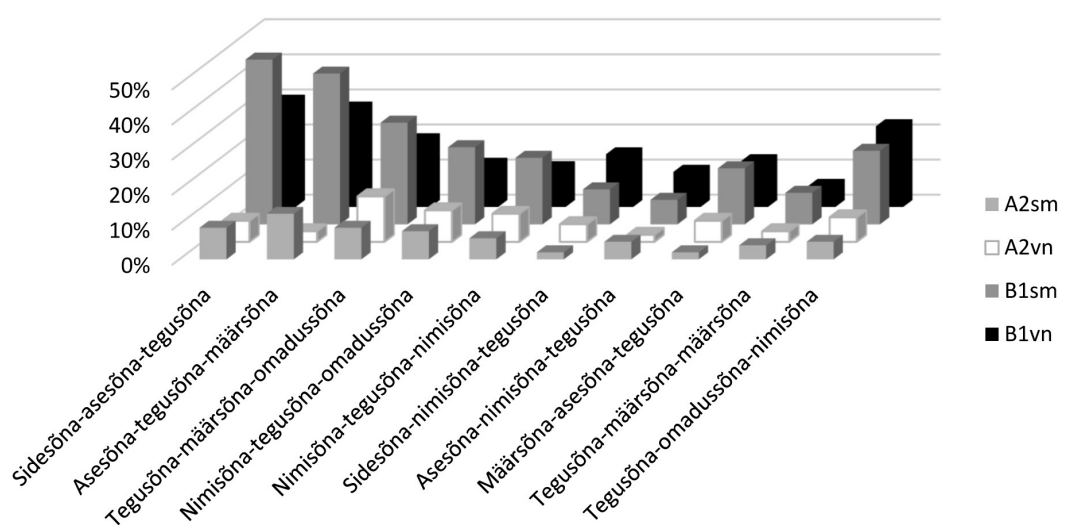

JoonIs 1. A2- ja B1-taseme kümne samastruktuurse mustri esinemus

Nii mõnelgi kümnest sama struktuuriga mustrist on emakeelekõneleja tekstiloomes (vrd Trainis \& Allkivi 2014) tunduvalt väiksem osakaal või ei mahu muster üldse statistiliselt oluliste hulka (nt tegusõna-määrsõnaomadussõna - on väga ilus; on eriti kaunis; määrsõna-asesõna-tegusõna Praegumalähen; kusma töötan; nimisõna-tegusõna-omadussõna - korter on suur; suvi on soe) ning vastupidi - emakeelekõneleja tekstides laialt levinud mustritel on õppijate keelekasutuses vähene osakaal (nt tegusõna-määrsõna-määrsõna - on tavaliselt sportlikult; on väga palju), mustri komponentidel on erinevad funktsioonid ja leksikaalgrammatiline varieeruvus (nt nimisõna-tegusõna-nimisõna - hoovis on mänguväljak; Liisa on näitleja; asesõna-nimisõna-tegusõna - Minu kodulinn on; Minu nimi on; tegusõna-omadussõna-nimisõna - on suur müra; on hea $\mathrm{ilm}$ ). Kuna keelekasutus on loominguline protsess, siis pole kuigi loogiline, et ka sama struktuuriga mustreid kasutataks ühtmoodi - erikeelsetest A2- ja B1-taseme õppijatest rääkimata.

Motiveerituna kindlast suhtlusvajadusest on soomekeelsetel õppijatel osa mustrite leksikaalgrammatiline varieeruvus B1-tasemel kitsenenud või kinnistunud A2-taseme variandis, nt nimisõna-tegusõna-omadussõna - tähendus on erinev; hotell oli väike; Elutuba on läbikäidav; valik oli õige; õues on ilus. Neid kasutatakse kitsamal suhtluseesmärgil, kuid 
tekstides leidub mustri struktuuri alusel rohkem näiteid kui venekeelsetel õppijatel. Kokkuvõttes: võrreldes A2-tasemega on soomekeelsetel óppijatel B1-tasemel mustri funktsioonid kitsenenud, kuid mustri kasutamine laienenud. See tähendab, et soomekeelsete õppijate keelekasutus on arenemas morfosüntaktiliselt ökonoomsema, kuid samas leksikaalselt mitmekesisema vormistuse suunas. Mustri nimisõna-tegusõna-omadussõna kvalitatiivse analüüsi tulemused näitavad, et selle struktuuri alusel rikastub soomekeelsete õppijate sõnavara, sh tegusõnade pagas (vt Eslon jt 2021: 160). Mustrit kasutatakse grammatiliselt kinnistunud, kuid leksikaalselt varieeruvana, mistõttu puuduvad tingimused stereotüüpsuse kujunemiseks. Sedalaadi nihked näitavad soomekeelse õppija liikumist sihtkeelepärase keelekasutuse suunas.

Kui võrrelda mustrite asesõna-nimisõna-tegusõna (Minu nimi on, vt Eslon jt 2021: 175-177) ja sidesõna-nimisõna-tegusõna (et haridus on, vt Eslon jt 2021: 170-172) osakaalu erikeelsete õppijate B1-taseme tekstides, siis selgub, et venekeelsetel õppijatel on esimese mustri osakaal väiksem ja teise osakaal suurem kui soomekeelsetel õppijatel, kuid mõlema mustri morfosüntaktiline varieeruvus on seevastu laiem. Näiteks mustris asesõna-nimisõna-tegusõna varieeruvad venekeelsetel õppijatel asesõnad (omastav, näitav, umbmäärane) ja nimisõna ainsuse-mitmuse käändevormid (seesütlev, nimetav), ent tegusõnadest esineb stereotüüpselt abitegusõna olema kindla kõneviisi ainsuse 3. pöördes (minu korter on; see üritus on; kõik ${ }^{*}$ studentid <üliõpilased> on; meie majas (elus, korteris) on). Soomekeelsed óppijad piirduvad A2-tasemel kinnistunud leksikaalgrammatilise variandiga Minu kodu on, milles leksikaalselt varieerub vaid nimisõna, kusjuures nimisõnade valik on suurem kui venekeelsetel õppijatel. See viitab mustri asesõna-nimisõna-tegusõna ekstensiivsele laienemisele venekeelsete õppijate tekstides, mille käigus sõnavara kuigi oluliselt ei täiene, küll aga muutub mitmekesisemaks mustri komponentide morfosüntaks. Analoogselt kasutavad venekeelsed õppijad ka mustrit sidesõna-nimisõna-tegusõna, kus vahelduvad nimisõna kääded (nimetav, seesütlev, alalütlev) ainsuses-mitmuses ning kõneliik (jaatav-eitav kõne), nt sest korter on; et ruumis on; et inimesel 
on; kui inimene ei, kuid tegusõna on stereotüüpselt kindla kõneviisi oleviku 3. pöördes, soomekeelsetel õppijatel ka lihtminevikus (aga tuul oli) ja eitava kõne näited neil puuduvad. Erinevus esimesest mustrist seisneb vaid selles, et venekeelsetel esineb siin lisaks abitegusõnale olema ka kaks modaaltegusõna (pidama, tahtma) ja üks täistähenduslik tegusõna (tegema), mis iseenesest ei kõnele veel tegusõna leksikaalse ja funktsionaalse mitmekesisuse kasuks. Tegemist on olukorraga, kus uudsete vormivalikutega ei kaasne kuigivõrd märgatavat sõnavara laienemist. Eelistatakse ühte kindlat tüüpi sõnastust, mille venekeelsed õppijad on omandanud. Sama tendents on esile tulnud ka venekeelsete õppijate kirjutamisprotsessis (vt Gaitšenja 2019).

Paradoksaalsel moel ilmneb venekeelsetelóppijatelleksikaalnestereotüüpsus rööpselt mustri morfosüntaktilise mitmekesisuse laienemisega isegi siis, kui konkreetne muster ei mahu sihtkeele analüüsi andmetel statistiliselt oluliste hulka (nt nimisõna-tegusõna-omadussõna - korter on suur; pere on väike; Tüdrukul on tore) või on väheoluline, ent samas avara leksikaalgrammatilise varieeruvusega (nt tegusõna-määrsõnaomadussõna - on väga sõbralik; on mõnevõrra tagasihoidlik). Tegemist on vastandlike tendentsidega õppija ja emakeelekõneleja keelekasutuses, mis võib viidata ebakindlusele sihtkeele vahendite ratsionaalsel valikul ja ökonoomsel kasutamisel, kuid võib viidata ka muudele õppimise ja õpetamisega seotud asjaoludele (õpetamise/õppimise strateegiad, õppematerjalid, metoodika). Paistab nii, et soomekeelsed õppijad on lähtunud põhimõttest vähem morfosüntaktaksit ning rohkem sõnavara, venekeelsed aga rohkem morfosüntaktiliselt varieeruvaid struktuure ja kesine sõnavara. Niisiis on väljaspool keelekeskkonda esile tulnud suundumus sõnavara omandamisele, keelekeskkonnas aga suundumus grammatika omandamisele. Nende tendentside kujunemist aitavad seletada eesti keele õppimise ja õpetamisega seotud asjaolud, kuid seni pole vastavaid analüüse tehtud. Seetõttu piirdutakse ka siin oletustega, mis erikeelsete õppijate keelekasutuse andmete põhjal oleksid loogilised.

Nihkes keelekasutusele viitab seegi, et õppijakeeles on üksjagu suur osakaal neil mustritel, mille esinemus sihtkeeles on vähene või 
statistiliselt ebaoluline. Niisugune on näiteks muster tegusõna-määrsõna-omadussõna (on küll hea; on väga huvitavad; oli natuke kurb; oli veel märg), mida eesti emakeelega inimesed kasutavad suhteliselt harva ning mille vormistus on selgelt piiritletud, kuid sõnavara rikkalik (on nii selge; olid hästi sõbralikud; avaneb sootuks uus lehekülg; tundus nii värske). Kui sedalaadi mustrite alusel laiendatakse õppijate sõnavara, siis on nende mustrite aktiivne kasutamine pedagoogiliselt õigustatud ja keele õpetamise mõttes on tehtud ratsionaalne valik teatud liiki leksikaalsete ja grammatiliste stereotüüpide ennetamiseks (õpetamise strateegia küsimus). Ent B1-taseme samastruktuursete mustrite keeleanalüüs näitas, et venekeelsed õppijad pole ka siin stereotüüpidest vabad, sest reeglina korratakse sõnakooslust on väga + omadussõna või keskvõrde vormi (on kõige parem) ja hulgasõnafraasi (on palju erinevaid). Põhjus seisneb endiselt kesises sõnavaras, konkreetsemalt määrsõnade minimaalses leksikaalses varieerumises, korratakse peaasjalikult kolme määrsõna (väga, kõige ja palju). Seevastu soomekeelsed õppijad kasutavad mustrit tegusõna-määrsõna-omadussõna sageli just tegusõnade, määrsõnade ja omadussõnade pagasi suurendamiseks.

Sisult teistlaadsed keelekasutuse nihked tulenevad õppija lähte- ja sihtkeele vahelistest seostest, milles väljenduvad kummagi keele süsteemsed iseärasused. Nii näiteks on venekeelsed õppijad eelistanud mustrit määrsõna-asesõna-tegusõna, kus esimene komponent on määruse, teine aluse ja kolmas öeldise funktsioonis (praegu ma saan; Kõigepealt see on; isegi ma olen). Ka soomekeelsed óppijad (Loodetavasti ma võin; seal ma saan; Loomulikult ma teen) ning emakeelekõnelejad kasutavad seda sõnajärge, kuid enamasti on neil siis mustri alguses asemäärsõna sidendi funktsioonis (kus ma töötan), mis eesti keeles normipärane, kuid mitte eriti levinud. Venekeelsed õppijad aga kasutavad selle mustri alguses erinevat liiki määrsõnu (nt Tavaliselt ma suusatan; enne ma tahaksin), mille puhul oleks loomulikum V2-sõnajärg (nt Tavaliselt suusatan $m a$ ), ent õppijad pole seda praktiseerinud. Niisugusel juhul oleks siiski loomulikum kasutada mustrit määrsõna-tegusõna-asesõna, kus esimene komponent on määruse, teine öeldise ja kolmas aluse funktsioonis ( $\underline{\text { Seal }}$ 
olen ma palju aega veetnud; praegu saan ma vaid kahetseda, et; Kõigepealt on see kallis: Loodetavasti võin ma ise otsustada; seal saan ma rahus olla). Rööpsete valikute olemasolul peab teadma, mis võimalik suulise spontaanse suhtluse korral, mis läbimõeldud keelekasutusega kirjutises, kus suhtluseesmärk tingib rangemat kinnipidamist keelekogukonnas aktsepteeritud sõnastustest. Taustal tuleb arvestada õppija lähtekeele mõjuga. Venekeelsete õppijate osas tähendab see seda, et lähtekeele normatiivne sõnajärg on määrus-alus-öeldis ning sõnajärg määrus-öeldisalus kuulub lähtekeeles ekspressiivse süntaksi vahendite hulka, mistõttu õppijad seda üldjuhul sihtkeeles väldivadki. Samas moodustuvad eesti keeles normatiivse V2-sõnajärje alusel keeleomased määrsõna-tegusõna kooslused, millega emakeelekõnelejal assotsieeruvad tüüpilised kasutuskontekstid, millest oli eespool juttu. Ja kuigi ka soomekeelsetele õppijatele tekitab eesti keele V2-sõnajärg raskusi, on nad B1-tasemel kasutanud koos järgneva asesõna ja tegusõnaga semantiliselt sobivaid lt- ja sti-lõpulisi subjektiivmodaalse ja hinnangulise tähendusega määrsõnu, samuti aega ja kohta tähistavaid määrsõnu, mis viitab mitte ainult diskursuse tunnetamisele, vaid ka vajaliku sõnavara olemasolule (k.a modaalsed ja liikumist väljendavad tegusõnad), millest venekeelsetel õppijatel jääb vajaka, vt ka vigaseid keelenäiteid nagu *väga ma tulen; *Veel ma või (töötan); ?isegi ma olen; *kaua ma elan. Samuti pole soomekeelsetel õppijatel tekkinud küsimusi määrsõnade semantikaga (nt juba, alles, äsja eristamine), mis eeldab arusaamist eestikeelsest ajaruumist.

Ka semantiliselt sobivate määrsõnakoosluste kasutamisel on omad reeglid, mida suhteliselt vähe analüüsitud, kuid mis loomulikus keelekasutuses laialt levinud. Näiteks B1-tasemel erikeelsete õppijate kirjutistes esile tulnud mustrit sidesõna-määrsõna-määrsõna eelistab emakeelekõneleja kasutada kolmes variandis: a) sagedam on ja ... nagu (ja vist/pisut/kuskilt nagu); b) järgnevad aga/ja ka ... (aga ka päris; ja ka natuke) ning c) ja/ning ... ka (ja muidugi ka; ning omamoodi $\underline{k a}$ ), vt Trainis \& Allkivi 2014: 295. Need on mustri sidesõna-määrsõna-määrsõna kolm kasutusreeglit, mida õppijad kahtlemata ei tunneta. Ka pole neid reegleid varem märgatudki, kirjeldamisest ja seletamisest rääkimata. 
Määrsõnakoosluste moodustumise ja kasutamise seaduspärasuste omandamist tuleks alustada sagedamast reeglist, varieerides leksikaalselt mustri sidesõna-määrsõna-määrsõna teist komponenti ning võrreldes sellega kaasnevaid tähendusmuutusi. Niisugust pedagoogiliste ja keeletehnoloogiliste rakenduste jaoks olulist teavet grammatikad ei sisalda, neid reegleid pole ka eesti keele kui teise ja võõrkeele õpikutes. Sama võib öelda mustri tegusõna-määrsõna-määrsõna kasutamise kohta, sest sihtkeelepäraste määrsõnakoosluste moodustumise seaduspärasusi tundmata hakatakse omavahel kombineerima kolme-nelja sagedamat määrsõna, nagu seda venekeelsed õppijad stereotüüpselt teevadki: on/ oli vaja palju; on/oli palju vaja; on/oli vaja väga; on/oli väga vaja; on/oli väga palju vaja jne.

Niisiis on mustri morfosüntaktiline struktuur ehk sõnaliikide regulaarne järgnevus tekstis ehk lihtsalt sõnajärg see raamistik, mille alusel kujunevad mustri lingvistilise varieeruvuse piirid. Selles on oluline roll sõnavaral, sest mustri semantiline mitmekesisus laiendab mustri morfosüntaktilise varieeruvuse piire, sidudes mustri kindlate leksikaalgrammatiliste variantide ja ühe või mitme keelekasutuse reegliga. Kesine sõnavara on keeleliste stereotüüpide kujunemise eeltingimus.

\section{Järeldusi}

Artikli sissejuhatavas osas esitatud küsimused, mis kerkisid soome- ja venekeelsete õppijate A2- ning B1-taseme keelekasutuse kohta mustrite esinemuse, nende leksikaalse ja morfosüntaktilise varieeruvuse statistiliste ja lingvistiliste andmete põhjal, said soostuva vastuse ning seletuse. Ühesuguse struktuuriga mustrite lingvistilise analüüsi tulemuste võrdlemisel õppijate kirjutatud tekstides ning emakeelekõneleja loomulikus keelekasutuses tuli esile, et

1) venekeelsed óppijad eelistavad mustrite loomuliku keelelise varieeruvuse asemel stereotüüpseid sõnastusi, samas kui soomekeelsete õppijate keelekasutust ilmestab leksikaalne mitmekesisus; 
2) üldjuhul on venekeelsetel õppijatel mustrite morfosüntaktiline varieeruvus avaram ja leksikaalne kitsam kui soomekeelsetel, kes eelistavad kindla morfosüntaktilise struktuuri alusel rikastada oma sõnavara.

Õppija sõnavara rikkus (eeskätt tegusõnad, määrsõnad ja määrsõnakooslused, sidesõnade valik) mõjutab samas ka mustri morfosüntaktilist varieeruvust. Näiteks abitegusõna olema kinnistumine lause tuumas jätab sisuliselt kõrvale kõik täistähenduslike tegusõnade kasutamisega võimalikud rektsioonistruktuurid, tüüpilised omadussõna-nimisõna ja määrsõnakooslused rikastavad õppijate keelekasutust kujundlike väljenditega jne. Soomekeelsete õppijate tegusõnade pagas on suurem, mustrites kasutatud omadussõna-nimisõna ja määrsõnakooslustega assotsieeruvad tüüpilised kontekstid, milles neid oleks võimalik kasutada jne. Niisiis on soomekeelsete õppijate keelekasutus klassiruumi tingimustes tervikuna sihtkeelepärasem kui venekeelsetel õppijatel keelekeskkonnas viibides.

Sama struktuuriga mustrite võrdleva analüüsi tulemused näitasid, et A2- ja B1-taseme tekstide sõnavara on temaatiliselt piiratud, mis on venekeelsete õppijate tekstides samuti stereotüüpsuse kujunemise allikas. Ka soomekeelsed õppijad kasutavad teemaga seotud sõnavara, kuid leksikaalseid stereotüüpe pole seejuures esile tulnud, kuna nende temaatiline sõnavara on avaram ja semantiliselt mitmekesisem. Selle põhjal võib oletada, et sarnaste teemade käsitlemisel on väljaspool keelekeskkonda tuginetud pigem sihtkeele autentsetele tekstidele kui mugandatud ja lühendatud õppematerjalidele, mida pakuvad eesti keele kui teise keele õpikud keelekeskkonnas. Alliktekstide lihtsustamisel kaob paratamatult koos teema käsitlusega seotud sisuliste aspektidega ka vastav sõnavara. Kõrvale jäävad väljendid, idiomaatika, vanasõnad ja kõnekäänud, mis rikastavad erikeelsete õppijate keele- ja kultuuriteadmisi, kujundavad arusaamu eestlaste mõttemaailmast, tõekspidamistest ja kultuurist. Vastasel juhul oleksid seotud sõnaühendid tulnud tasapisi kasutusse kohe õpingute alguses. Venekeelsete õppijate B1-taseme tekstides leidub üksikuid seotud sõnaühendeid, kuid puuduvad ühend- ja väljendtegusõnad, 
esile on tulnud ebatavalised sõnakooslused, milles puudub loogika ning mida soomekeelsetel õppijatel ei esine. Kolmandik neist on sedavõrd absurdsed, et ei assotsieeru emakeelekõnelejal ühegi kontekstiga, kuhu need võiksid sobida. Üldiselt on aga teada, et just õpingute algetapil kopeerib õppija allikteksti sõnastusi väga suures ulatuses. Samas oleks peaaegu iga statistiliselt olulise mustri põhjal tegelikult võimalik laiendada õppija sõnavara ka seotud sõnaühendite, kollokatsioonide ja idiomaatiliste üksustega. Näiteks mustri määrsõna-omadussõna-nimisõna alusel võib tuletada kujundlikke omadussõna-nimisõna kooslusi (mõneti kummaline lugu; tõesti süütu kurat), mõne teise struktuuriga mustri põhjal nt väljendeid (kurat võtaks; kurat teab; kes kurat; käi kus kurat) ja idiomaatikat (viinakurat kallal; kurat on jumala tööriist; sa tuline kurat). See on võimalik, kui keeleõpe ei taandu teemakesksele õpetamisele ja kitsalt teemaga seotud sõnavarale, kui kasutatakse lihtsustamata ja lühendamata keelelist allikmaterjali. Venekeelsete õppijate sõna- ja vormikasutuse eelistused näitavad päris hästi, et sõnavara teadlik omandamine autentsele keelematerjalile tuginedes ei ole olnud õpetamise ega õppimise fookuses. Võimalikud lahendused tulenevad õpetamisel ja õppimisel rakendatud strateegiatest ning nende seostest muud tüüpi strateegiatega, nt inimeste vahelise suhtluse, keeleressursside ja sõnavara kasutamise, lugemise jm strateegiad (vt nt Griffiths 2003).

Oppijate keelekasutuses esineb nihkeid mustri komponentide loomulikus järgnevuses, sõnavormide omavahelisel kombineerimisel ja komponentide süntaktilistes funktsioonides. Suures plaanis on see loomulik, sest A2- ja B1-tasemel pole õppijatel kujunenud emakeelse inimese keelekasutust reguleerivat tasakaalu mustrite leksikaalse, morfosüntaktilise ja funktsionaalse varieeruvuse ning keelendite optimaalse, ent samas ratsionaalse valiku ja ökonoomse kombineerimise vahel.

Omandanud võimalikult suure sõnavara väheste sageli esinevate morfosüntaktiliste mustrite alusel, suudavad soomekeelsed óppijad ennast sihtkeeles selgemalt väljendada ja edasi anda rohkem teavet kui venekeelsed õppijad morfosüntaktiliselt varieeruvate mustrite, kuid 
kesise sõnavara (eriti määrsõnade ja tegusõnade) pagasi ja leksikaalsete stereotüüpidega. Muide, siin peitub üks võimalik vastus Noam Chomsky küsimusele, miks saab väheste andmete juures nii palju teada ja kuidas võib suure hulga andmete korral omada nii kitsaid teadmisi (vt Chomsky 1986: xxv). Ehk teisisõnu, kuidas saab nii vähese hulga mustritega nii palju edasi anda (ratsionaalsed leksikaalgrammatilised valikud ja ökonoomsed keelestruktuurid) ning kuidas võib nii suure hulga mustrite abil nii vähe öelda (leksikaalgrammatiliste valikute paljusus ja kesine sõnavara). Seda Chomsky paradoksi annab laiendada keelekasutusele tervikuna.

Õppijate tekstides esile tulnud mustrite keeleanalüüsi tulemuste põhjal saab üsna suure tõenäosusega järeldada, et sihtkeele infovälja piiratus on õppijatel seotud põhiliselt kahe asjaoluga: a) autentsed allikmaterjalid - õppeteksti sõnastusi kopeeritakse ja jäetakse meelde väga olulises mahus (eriti õpingute algetapil), mistõttu, tuginedes lühendatud ning lihtsustatud õppematerjalidele, ei omandata autentsele keelekasutusele omaseid struktuure ja tüüpilisi sõnakooslusi; b) sihtkeele loominguline kasutamine, milleks tuleb teada keele elementide kombineerimise võimalusi ehk kooskasutuse reegleid - emakeelekõnelejate tekstiloomes kas alateadlik (keelepädevuse põhjal kujunenud automatism) või taotluslik (juhindutakse erinevatest praktilistest või loomingulistest vajadustest). Nendele reeglitele tugineb emakeelekõneleja keeleline loovus. Samas ei tea me teksti keeleloome kui protsessi ega keele elementide kooskasutuse reeglite kohta kuigi palju, ehkki neid teadmisi oleks vaja keele õpetamisel ja õppimisel, et õppija keelekasutuse eelistused kujuneksid sihtkeelele iseloomulike sõnastuste alusel, mitte nende suhtes nihkes. Emakeelekõneleja tekstides sageli kasutatud mustritel jm liiki kõnevormelitel on sihtkeele õpetamisel, õppimisel ja omandamisel kindel roll. Keeleõppes on mustrid vajalikud ja kasulikud, kuid tundmata nende kasutusreegleid, samuti mustrist vasakule ning paremale hargneva konteksti tüüpilist sõnastamisviisi, jääb õppija infoväli paratamatult puudulikuks, mistõttu sihtkeele vahendeid kombineeritakse intuitiivselt, stereotüüpe ja (vale)analoogiat rakendades. 
Nihe emakeelekõneleja igapäevase keelekasutusega võrreldes võib olla ka taotluslik (nt sõnade kasutamine ülekantud tähenduses, mõistu ütlemised jmt), kuid selle avaldumise viisid ja vormid on alati individuaalsed. Lähtekeele ja teiste varem omandatud keelte põhjal on õppijad sellest võimalusest sisemas teadlikud, kuid õpingute algetapil on tavaliselt fookuses sõnade ja vormiparadigmade omandamine, kõnevormelid (nt etiketi nõuded) jmt. Sel etapil tekkinud nihked ei ole taotluslikud, vaid paratamatud. Alles infovälja laienedes on õppija võimeline ühel või teisel määral võrdlema ning tajuma erinevusi oma ja sihtkeelepäraste sõnastuste vahel, mis lubab tal väljenduslaadi täiustada ja oma keeleoskust arendada. Kui õppija hakkab seda enesele teadvustama, siis muutub keeleõpe tema jaoks teadlikuks tegevuseks, millega rööpselt laieneb õppija infoväli ning luuakse eeldused keele elementide loominguliseks kasutamiseks. Seetõttu on kõigele lisaks tähtis, et õpingute algusest peale kujuneksid tõesed, mitte väärad analoogiaseosed lähte- ja sihtkeele süsteemide vahel. Üldjuhul pole aga lähte- ja sihtkeele lähedus või erinemine soome- ja venekeelsete õppijate sihtkeele omandamist ei märgatavalt soosinud ega pärssinud. Pigem pärsivad keeleoskuse kujunemist õpetamise ja õppimise strateegiatest tulenevad asjaolud, väärad juhised ja valeanaloogiad, lühendatud ja lihtsustatud õppematerjalide eelistamine autentsetele terviktekstidele jne. Ilmselt tuleb siit otsida põhjusi, miks venekeelsete õppijate keelekasutuses ei tule esile keelekeskkonna toetavat mõju.

\section{Kirjandus}

Chomsky, Noam 1986. Knowledge of Language: Its Nature, Origin, and Use. Convergence. A Series Founded, Planned, and Edited by Ruth Nanda Anshen. Westport-Connecticut-London: PRAEGER, 1986.

Eslon, Pille, Annekatrin Kaivapalu, Katre Õim, Mare Kitsnik, Olga Gaitšenja, Kais Allkivi-Metsoja 2021. Eesti keele oskuse arenemine ja arendamine. Kirjalik õppijakeel ['Development of Estonian Language Proficiency. Written Learner Language']. Tallinn: EKSA. 
Eslon, Pille, Annekatrin Kaivapalu 2020. Teel sihtkeelepärase keelekasutuse poole: vene- ja soomekeelsete eesti keele õppijate kirjaliku keelekasutuse dünaamika A2- ja B1-tasemel ['Towards target-like language use: Russian and Finnish learners' dynamics of written Estonian on A2- and B1-level']. Lähivõrdlusi. Lähivertailuja 30, 57-88. https://doi.org/10.5128/LV30.01

EVKK = Eesti vahekeele korpus. http://evkk.tlu.ee (12.2.2021).

Gaitšenja, Olga 2019. Venekeelsete eesti keele õppijate kirjutamisprotsess ['The Writing Process of Native Russian-Speaking Learners of Estonian']. Humanitaarteaduste dissertatsioonid 51. Tallinn: Tallinna Ülikool.

Griffiths, Carol 2003. Patterns of language learning strategy use. - System 31 (3), 367-383. https://doi.org/10.1016/S0346-251X(03)00048-4

Hint, Mati 2017. Partitiivi laienemine aspektituks objektikäändeks ['Expansion of partitive case in the Estonian language into a counterpart of Indo-European accusative']. - Mäetagused 69, 153-180. https://doi.org/10.7592/ MT2017.69.hint

Trainis, Jekaterina, Kais Allkivi 2014. Ilukirjanduskeelest uue pilguga ['On belletristic language from a new perspective']. - Eesti Rakenduslingvistika Ühingu aastaraamat 10, 283-306. https://doi.org/10.5128/ERYa10.18

\section{Pille Eslon}

Tallinna Ülikool, digitehnoloogiate instituut

Narva mnt 29, 10120 Tallinn, Estonia

peslon@tlu.ee 


\title{
On the language use patterns of Finnish- and Russian- speaking learners of Estonian at the levels A2 and B1: Variability vs. stereotypicality
}

\author{
PILLE ESLON \\ Tallinn University
}

Comparative analysis of the language use patterns of Finnish- and Russianspeaking learners of Estonian as a target language reveals different tendencies in their A2- and B1-level written production. This article discusses the development of lexico-grammatical variability and stereotypicality which may relate to some factors that influence language learning, such as learning and teaching strategies and the used learning resources. The presented study aimed to explore preferences in combining parts-of-speech, the choice of vocabulary and grammatical forms by native Finnish and Russian speakers learning Estonian, compared to native users of Estonian. Relying on the frequency of part-ofspeech $n$-grams as well as the morphosyntactic variability and lexical diversity within these recurring patterns, the analysis indicates that the vocabulary of Finnish-speaking learners expands, while lexico-grammatical stereotypes become rooted in the writings of Russian-speaking learners. The formation of stereotypicality is caused by a) lack of adverbs in the learners' lexicon (Finnish learners have a richer vocabulary in terms of adverbs) and limited use of lexical verbs (varies more in the texts written by Finnish learners); b) functional deviations in combining parts-of-speech and grammatical forms in text when compared to native speakers (concerns Russian learners). Diverse vocabulary also extends the constraints of morphosyntactic variability.

Keywords: language use patterns; lexico-grammatical variability; learner language; Estonian 